\title{
Influence of information systems on organizational results
}

\author{
Influencia de los sistemas de información en los \\ resultados organizacionales

\section{Demian Abrego Almazán*, Yesenia Sánchez Tovar, José M. Medina Quintero}

Universidad Autónoma de Tamaulipas, Mexico

Received 17 March 2015; accepted 9 February 2016

Available online 31 March 2017

\begin{abstract}
In recent years, information systems (IS) comprise one of the main fields of study in business organization, caused by the need to identify their business value. Therefore, in this research and based on a theoretical review, a model is developed for the evaluation of the success of the IS for small and medium enterprises (SME) to determine the influence of the IS in the organizational results. To reach this goal, the Partial Least Squares (PLS) statistical technique was used through a survey made to 133 companies of Tamaulipas state, Mexico. The results obtained allow deducing that the companies that pay more attention on improving the quality of the system, of the information, and of the information systems, favor their organizational results. This work contributes to the literature on the measurement of the success of the IS in the context of a country with an emerging economy, particularly by allowing to identify in a broader manner the measurement of its effectiveness and its incidence in the business performance.

(C) 2017 Universidad Nacional Autónoma de México, Facultad de Contaduría y Administración. This is an open access article under the CC BY-NC-ND license (http://creativecommons.org/licenses/by-nc-nd/4.0/).
\end{abstract}

JEL classification: M15

Keywords: Information systems success; Partial Least Squares; Organizational outcomes

\footnotetext{
* Corresponding author.

E-mail address: dabrego@uat.edu.mx (D. Abrego Almazán).

Peer Review under the responsibility of Universidad Nacional Autónoma de México.
} 


\section{Resumen}

Durante los últimos años los sistemas de información (SI) han constituido uno de los principales ámbitos de estudio en el área de organización de empresas, ocasionado por la necesidad de identificar su valor empresarial, por lo que, en esta investigación, y en base a una revisión teórica, se desarrolla un modelo de evaluación del éxito de los SI para las pequeñas y medianas empresas (Pymes) con el objetivo de determinar la influencia de los SI en los resultados organizacionales. Para alcanzar la meta, se empleó la técnica estadística de mínimos cuadrados parciales (partial least squares, [PLS]), mediante la aplicación de un cuestionario a 133 empresas del estado de Tamaulipas, México. Los resultados obtenidos permiten deducir que las empresas que se preocupan más por mejorar la calidad del sistema, la calidad de la información y la del servicio informático favorecen sus resultados organizacionales. El presente trabajo contribuye a la literatura sobre la medición del éxito de los SI en el contexto de un país con una economía emergente, en forma particular al permitir identificar de manera más amplia la medición de su efectividad y su incidencia en el rendimiento empresarial.

(C) 2017 Universidad Nacional Autónoma de México, Facultad de Contaduría y Administración. Este es un artículo Open Access bajo la licencia CC BY-NC-ND (http://creativecommons.org/licenses/by-nc-nd/4.0/).

Códigos JEL: M15

Palabras clave: Éxito de los sistemas de información; Mínimos cuadrados parciales; Resultados organizacionales

\section{Introduction}

Information systems are one of the most relevant components of the current business environment. They offer great opportunities for success for the companies; given that they have the capability of collecting, processing, distributing, and sharing data in an integrated and timely manner. Furthermore, they help narrow geographical gaps, allowing employees to be more efficient, which is reflected in an improvement of the processes, administration, and the management of information, thus resulting in a positive impact on the productivity and competitiveness of the companies (Bakos \& Treacy, 1986; Rai, Patnayakuni, \& Seth, 2006; Ynzunza \& Izar, 2011).

However, these advantages make the organizations more dependable on the IS to carry out their day to day activities (Gómez \& Suárez, 2012), which forces them to invest more in this type of technologies (Petter, DeLone, \& McLean, 2008). Nevertheless, the concerns regarding the economic scenarios and the growing global competency create pressures to reduce them (Derksen \& Luftman, 2013; Petter et al., 2008). Therefore, organizations require measuring and examining the costs and benefits of this type of technology to better know the profitability of the investments made, given that these are expected to generate positive returns for the institution (Gable, Sedera, \& Chan, 2008; Ravichandran \& Lertwongsatien, 2005).

This investigation has the objective of determining the influence of the success of the IS on the organizational results (OR). For a company, the OR allow measuring its operational efficiency (Sedera \& Gable, 2004). In this scope, the model developed by DeLone and McLean $(1992,2003)$ to evaluate the success of the IS has proven to be a useful framework to deduce its success or effectiveness (Petter, DeLone, \& McLean, 2013) by recognizing that the quality dimensions of the IS are a distinctive characteristic of the perception of the user in the use of new technologies (Solano, García, \& Bernal, 2014); thus, achieving a positive impact on the individual and organizational performance (DeLone \& McLean, 2003).

Therefore, an empirical study has been carried out with 133 SMEs from the state of Tamaulipas, Mexico, to statistically infer some aspects related to this type of organizations. From this aspect, 
the contribution of this work is considered relevant, as it broadens the framework of empirical studies related to the IS success model proposed by DeLone and McLean.

Finally, this investigation has been divided into five parts: the first comprises a review of the literature; the second has the proposed model and its justification; the third presents the description of the method utilized; the fourth comprises the analysis of the results; and, finally, the fifth section presents the main conclusions obtained, describing the limitations and future lines of research.

\section{Review of the literature}

\section{Information systems and their success}

The IS of a company represents the combination of human and material means in charge of processing the business information (Medina, 2005), having a relevant role and being the cause of competitive advantages (Ferreira \& Cherobim, 2012). Information Systems use computer equipment, databases, software, procedures, analysis models, and decision-making administrative processes (Turban, Volonino, \& Wood, 2013). Traditionally, ISs are designed within each functional area to support and increase their efficiency and operational efficacy (Haag \& Cummings, 2013). Information Systems are characterized by being comprised of smaller systems, capable of functioning either in an integrated manner or independently. Furthermore, if they are able to interrelate, they can comprise the IS of the entire organization, therefore, an IS can be defined as the group of elements focused on processing, administering, and disseminating data and information, organized and ready for their subsequent use, generated to cover an organizational need. This is similar to the ideas posed by Davis and Olson (1985), Andreu, Ricart, and Valor (1996), Haag and Cummings (2013), and Turban et al. (2013).

Since the 1970s, the measurement of the impact of the success of the IS has been researched with different studies enabling the accumulation of important knowledge on the topic (Solano et al., 2014). Among the different movements that embrace the importance of the IS, we can find the one based on the theory of resources and capabilities (Ravichandran \& Lertwongsatien, 2005) or the one related to the software industry. The latter is the one in which different quality management models have been proposed, some focused on the products and others on the processes (Pesado et al., 2013). This allows an improvement in productivity with regard to software development (Díaz \& Sligo, 1997). Nevertheless, a focus integrated in the context of the Information Systems is deficient, given that there is less emphasis regarding the quality improvement of the information and the service (Gorla, Somers, \& Wong, 2010).

In this sense, DeLone and McLean (D\&M) have proposed, since 1992, a model that allows measuring the impact that the IS provide to the organization, and given the acceptance and critiques it had by the researchers, it was updated in 2003 (Roldán \& Leal, 2003). The inclusion of the quality service construct was among the main changes, being evaluated mainly through SERVQUAL. In this update, the observation of its main critic-Peter Seddon-which indicated replacing the individual and organizational impact variables for the net benefits variable was also addressed (DeLone \& McLean, 2003).

According to Ballantine et al. (1996), Seddon (1997), and Wu and Wang (2006), the model by DeLone and Mc Lean makes several significant contributions to the understanding of the success of the IS. Firstly, it provides a diagram to classify the different measurements of success that have been proposed in the literature. Secondly, it suggests temporary and causal interdependencies between the identified categories; and thirdly, it provides an appropriate base for further empirical and theoretical research. Because of this, it has a general acceptance in the IS community, in part 
due to its intelligibility and simplicity (Urbach, Smolnik, \& Riempp, 2009), as this model is one of the most referenced in the literature of Information Systems (Gable et al., 2008; Gorla et al., 2010; Heo \& Han, 2003; McGill \& Hobbs 2003; Medina \& Chaparro, 2007; Petter et al., 2008, 2013; Urbach et al., 2009).

Regarding its interrelations, the model proposes that the quality dimensions (of the system, information, and service) of an IS affect both the use-utility of the system as well as the satisfaction of the user. It proposes that the latter in turn can be affected reciprocally, in addition to being direct antecedents of the net benefits. This allows it to be applied to any level of analysis that the researcher considers most relevant (Gorla et al., 2010; Igbaria \& Tan, 1997; Petter et al., 2008; Roldán \& Leal, 2003; Seddon \& Kiew, 1994). Therefore, this model is characterized for trying to find more consistent and appropriate measurements for an adequate evaluation of the IS (Solano et al., 2014).

\section{Organizational impact}

Currently, the companies are obligated to be connected to each other and to other organizations, as a consequence of fusions, reduction in the costs of operation, and market strategies, among others. Therefore, the need for investment on Information Systems is an non-debatable fact, but its high cost entails the interest of the company in having a successful implementation and integration with the institutional objectives. However, empirical evidence points out that the sole investment in IS and in new management tools does not guarantee the improvement of the business results (Lee, 2012; Pérez \& Machado, 2015). And this drives the academia to delve further in the knowledge of the explicative factors of the success of the IS and their impacts on the companies.

The explanation of the effects generated by the IS in the organizations have led researches to propose evaluation instruments that consider organizational strategy and competitiveness advantage as impact variables (Bradley, Pridmore, \& Byrd, 2006; Gable et al., 2008; Mahmood \& Soon, 1991; Sethi \& King, 1994; Tallon, Kraemer, \& Gurbaxani, 2000). Whereas others try to evaluate this relationship based on the theory of resources and capabilities, in which the performance of an organization can be explained by the efficiency of the business when it makes use of information technology (Ravichandran \& Lertwongsatien, 2005). However, regardless of the focus, the search for organizational benefits or positive effects becomes the objective of the businesses as a key element for the decision to invest in IS.

The aforementioned forces researchers to define conclusive measurements for the desired organizational result, with examples such as economic profitability, net value, utility and growth, marketing achievements, improvement on productivity, internal efficiency, innovation, improvement in the quality of the products, cost reduction, better relationship with providers, decision making ... among others; detecting in their results the existence of significant relationships between the dimensions of success of an IS and the perceived benefits (Bradley et al., 2006; Gonzáles, 2012; Gorla et al., 2010; Haberkamp, Maçada, Raimundini, \& Bianchi, 2010; Lunardi, Dolci, \& Maçada, 2010; Pérez \& Machado, 2015; Rai et al., 2006; Sedera \& Gable, 2004; Solano et al., 2014; Tona, Carlsson, \& Eom, 2012).

These research works have demonstrated that the organizational impact construct can refer to the degree in which the IS have promoted improvements at the organizational level, that is, improvements in their organizational results. Nevertheless, this construct has proven to be problematic in business research (Ynzunza \& Izar, 2011) and, given that there is no recognized universal measurement for this concept, it can be evaluated with objective and subjective data (Croteau \& Bergeron, 2001), where the objective approach refers to the numerical data of a 


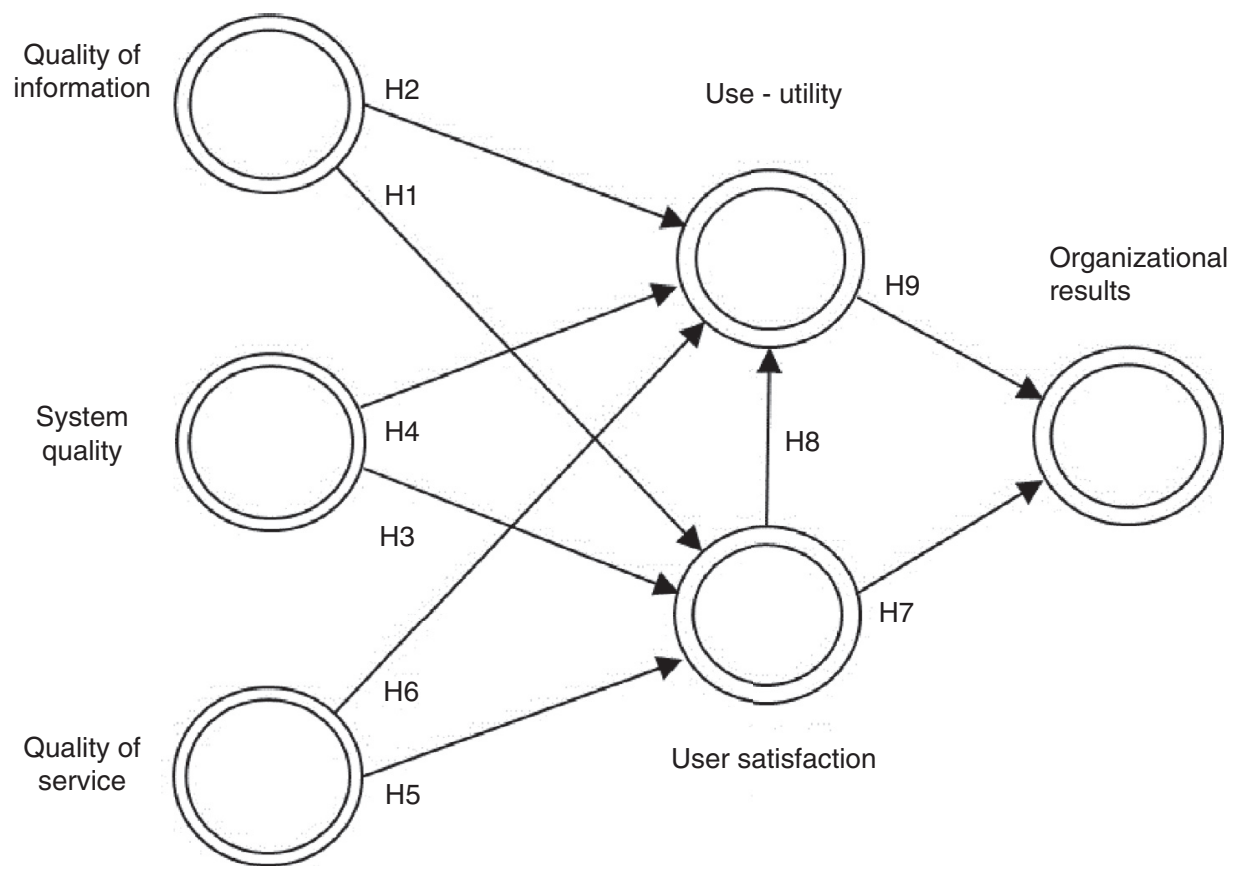

Fig. 1. Conceptual model and hypothesis.

financial nature provided by the organization, whereas the subjective measures focus on capturing the perception of the businesses.

Without a doubt, IS are a vital technological tool for any institution in this period of globalization, where the efficient administration of data and information brings with it a competitive business advantage.

\section{Research model and hypothesis}

The conceptual model utilized to guide this study is shown in Fig. 1, and is based on the model proposed in 2003 by D\&M. The model explains that the quality of the system, of the information, and of the service affect both the use-utility of the system as well as the user satisfaction. However, it is important to mention that it has been proposed that the service quality variable should not be considered a determining measurement of success, given that said construct establishes success instead of being a part of it (Tona et al., 2012; Wu \& Wang, 2006). In this study, however, it is considered a relevant factor to be evaluated, as consequence of the growing demand for external providers of Information Technology (IT) for the development and support of systems, especially in businesses that due to their size, economic issues, or business strategies, do not have sufficient human and technological resources allocated for such purposes.

On the other hand, according to Roldán and Leal (2003), user satisfaction influences the use of the system. It is worth noting that DeLone and McLean (2003) postulate that the use-utility of the system and user satisfaction are reciprocally interdependent, but Livari (2005) notes that for a thorough analysis, an investigation ought to be carried in which the use-utility and user satisfaction are monitored over time. Consequently, this is not an attempt to capture this reciprocal dependency 
Table 1

Hypotheses to be tested.

Conceptual model
The quality of the system, the quality
of the information, and the quality of
the service of an IS, individually and
collectively affect both the
use-utility of the IS as well as the
user satisfaction.

$\mathrm{H} 2$ : The quality of the information is positively associated to the use-utility of the system.

H3: The quality of the system is positively associated to user satisfaction.

H4: The quality of the system is positively associated to the use-utility of the system.

H5: The quality of the service is positively associated to user satisfaction.

H6: The quality of the service is positively associated to the use-utility of the system.

The degree of user satisfaction can affect the use-utility of the IS.

The Use of the IS and user satisfaction are direct precedents of the Organizational Results.
H8: User satisfaction is positively associated to the use-utility of the system.

H7: User satisfaction and Organizational Results are interrelated.

H9: The use-utility of the system and Organizational Results are interrelated.
Additional supporting references

Wixom and Watson (2001), Rai,

Lang, and Walker (2002), Shin

(2003), McGill and Hobbs (2003),

Roldán and Leal (2003), Wixom and

Todd (2005), Halawi, McCarthy, and

Aronson (2007), Pérez (2010), Nunes (2012).

Rai et al. (2002), Roldán and Leal (2003), McGill and Hobbs (2003), Fitzgerald and Russo (2005), Pérez (2010).

Choe (1996), Chen, Soliman, Mao, and Frolick (2000), Hwang, Windsor, and Pryor (2000), McGill and Hobbs (2003), Roldán and Leal (2003), Halawi et al. (2007), Kim, Moon, and Kim (2012), Nunes (2012).

Hwang et al. (2000), Caldeira and Ward (2002), McGill and Hobbs (2003), Roldán and Leal (2003), Fitzgerald and Russo (2005), Pérez (2010).

Pitt, Watson, and Kavan (1995), Halawi et al. (2007), Bharati and Berg (2005), Bharati and Chaudhury (2006), Kettinger et al. (2009), Kim et al. (2012), Nunes (2012).

Pitt et al. (1995), Caldeira and Ward (2002), Fitzgerald and Russo (2005), Wu and Wang (2006), Pérez (2010).

Baroudi, Olson, and Ives (1986), Torkzadeh and Dwyer (1994), McGill and Hobbs (2003), Roldán and Leal (2003), Livari (2005), Bokhari, 2005; Wu and Wang (2006), Qutaishat, Khattab, Zaid, and Al-Manasra (2012), Nunes (2012). McGill, Hobbs, and Klobas (2000), McGill and Hobbs (2003), Roldán and Leal (2003), Wu and Wang (2006), Pérez (2010), Nunes (2012). McGill and Hobbs (2003), Roldán and Leal (2003), Wu and Wang (2006), Law and Ngai (2007), Pérez (2010).

given that it is limited to a single point in time. Finally, the proposal is that the use-utility of the system and user satisfaction are direct precedents to the organizational results.

As can be observed in Fig. 1, the hypotheses to be tested are also represented, summarized in Table 1, where the theoretical support provided by the DeLone and McLean model $(1992,2003)$ 
can also be observed. An additional relation of references of studies on IS that support them is annexed.

\section{Method}

To analyze the success of the IS in companies of the private sector in Tamaulipas state, a prior review of the specialized literature was carried out in order to: (i) approximate to the problematic detected with regard to the success of the IS in the organizations in the area of study; (ii) know the theoretical model of DeLone and McLean more in depth; (iii) justify and contend the work hypotheses; and (iv) define, determine, and adjust the indicators and factors of the proposed constructs. Below, we present its operational definition.

- Information quality, defined in this work as complete, timely, useful, relevant, with good appearance and format (adequate design) that is easy to understand and interpret (Ballou \& Tayi, 1999; DeLone \& McLean, 1992, 2003; Gorla et al., 2010; Medina, Lavín, \& Pedraza, 2011; Nelson, Todd, \& Wixom, 2005; Petter et al., 2008; Tona et al., 2012; Wixom \& Watson, 2001).

- System quality, is defined as the IS designed with useful characteristics, with adequate response times, easy to learn-use, with an adequate level of integration (Bradley et al., 2006; DeLone \& McLean, 2003; Gorla et al., 2010; Sabherwal, Jeyaraj, \& Chowa, 2006; Seddon, 1997; Tona et al., 2012; Wixom \& Watson, 2001).

- Service quality, measured through matters related to the response capacity, and intended to evaluate the degree of effort of the IT support personnel to provide the adequate elements and information services to the users (Bradley et al., 2006; Carr, 2002; Gorla et al., 2010; Kettinger \& Lee, 1994; Vázquez, 2015).

- User satisfaction, is specified as how the user feels after using the system (confidence), if they perceive that it has been efficient, effective, and if it is in agreement with their needs (Gonzáles, 2012; Medina et al., 2011; Tona et al., 2012; Wu \& Wang, 2006).

- Use-utility, is defined as follows: if when using the system, the user perceives that they carry out their functions faster, that their work performance improves, and that their productivity increases, then they can make better decisions; and if they find the system useful for work and not just for measuring it through general use, average use or the average duration of use (Gonzáles, 2012; Livari, 2005; Medina \& Chaparro, 2007; Seddon, 1997; Taylor \& Todd, 1995; Tona et al., 2012; Wu \& Wang, 2006).

- Organizational Results, in this investigation these are considered as an increase in sales, market quota, productivity, improvement on the processes, in their capacity of operations management, or in the decrease of operational and personnel costs (Gable et al., 2008; Gorla et al., 2010; Haberkamp et al., 2010; Mahmood \& Soon, 1991; Rai et al., 2006; Sedera \& Gable, 2004; Sethi \& King, 1994; Tallon et al., 2000).

Regarding the survey, it was comprised of 46 items, 8 for descriptive data and 38 in a Likert scale of 5 points (1, Strongly disagree -5 , Strongly agree). As for the pilot test, it was carried out in the central zone of the Mexican state of Tamaulipas, on April 2014, with a sample size of 65 companies. The internal consistency results of each of the theoretically proposed variables were evaluated by the Cronbach's Alpha coefficient, surpassing the recommended minimums for this type of analysis. It is worth mentioning that the results of this preliminary study were presented in the IX International Congress of Research in Accounting, Administration, and Informatics, carried out by the UNAM on October 2014. 
The sample was obtained parting from the records provided by the Mexican Business Information System (Sistema de Información Empresarial Mexicano; SIEM, http://www.siem.gob.mx) where, for May 2014, 1528 companies were registered in the state of Tamaulipas, all complying with the selection criteria stipulated in this investigation-to have more than 10 employees and to be from the service and commerce economic sectors. After identifying the participating companies, the corresponding authorization was processed with the different Chambers and Trade and Service Associations of the locality for the support in the implementation of the instrument.

The field work was carried out through convenience sampling, and the data collection was done between November 2014 and February 2015, through on-site visits to the companies, explaining the objective of the study to the key informant (subject of investigation). In this case, the key informants addressed were the general and accounting managers, as they comply with the desired profile-having information on the business processes and IT knowledge (Ferreira \& Cherobim, 2012; Gorla et al., 2010). The final sample achieved for this investigation was of 133 companies belonging to the commerce and service sectors.

\section{Data analysis and results}

First of all, the findings regarding the descriptive data are presented. From the companies that comprised the sample, $16 \%$ correspond to companies situated in the city of Reynosa, $15 \%$ to Nuevo Laredo, $19 \%$ to Matamoros, $27 \%$ to Ciudad Victoria, and $23 \%$ to Tampico and its urban area. Regarding the economic sector to which they belong, $41 \%$ are service companies and the remaining $59 \%$ belong to the commerce sector. As for the number of employees of the companies analyzed, $59 \%$ of the companies had an average of $11-30$ employees, $14 \%$ had a total of 31-50 employees, whereas $11 \%$ had more than 50 but less than 100 employees, and finally $17 \%$ of the companies corresponded to organizations with an average of 101-250 employees. For its part, it stands out that $61 \%$ of the analyzed companies have been using technologies for more than 10 years, which allows to infer that companies tend to use IS to obtain information and to manage their operations.

For the analysis of the data, the modeling of structural equations based on components/variance was utilized, implementing the SmartPLS version 3.1.3 informatics pack (Ringle, Wende, \& Becker, 2014). To validate the measurement model, the following proceedings were carried out: (i) analyze the content validity and the apparent validity; (ii) calculate the individual reliability of the item through the loading for the case of reflective constructs; and (iii) examine the construct validity: convergent and discriminant.

Regarding the validity of the content, a review was carried out on the literature specialized in the general systems theory, on the IS evaluation models, and on the impact of the IT services in the organizations. Similarly, an adaptation of the initially proposed measurement scales was done. For this purpose, the apparent validity was verified, which allows to indicate if the measurement scale appears to be valid, and that it is understood from the point of view of the survey (Casaló, Flavián, \& Guinalíu, 2011). The aforementioned allowed performing a filtering of items by different researchers and experts specialized in the subject matter, guaranteeing satisfactory results, as suggested by Straub (1989).

To validate the measurement model, a series of tests were carried out with the purpose of determining if the survey had the reliability required. In this sense, the first test focuses on determining the individual reliability of the indicators, which consists in accepting an indicator or not as a component of a reflective construct. For this, the indicators must have a factorial load $(\lambda)$ or simple correlations equal to or greater than 0.707 (Carmines \& Zeller, 1979). This indicates 
Table 2

Individual reliability of the indicators.

\begin{tabular}{|c|c|c|c|c|c|c|c|c|}
\hline \multicolumn{3}{|c|}{ Information quality (IQ) } & \multicolumn{3}{|c|}{ System quality (SQ) } & \multicolumn{3}{|c|}{ Service quality (SerQ) } \\
\hline Item & Load & $T$-statistic & Item & Load & $T$-statistic & Item & Load & $T$-statistic \\
\hline IQ1 & 0.901 & 42.573 & SQ1 & 0.794 & 21.599 & SerQ1 & 0.862 & 25.182 \\
\hline IQ2 & 0.868 & 27.982 & SQ3 & 0.708 & 10.464 & SerQ2 & 0.893 & 38.914 \\
\hline IQ3 & 0.866 & 30.055 & SQ4 & 0.800 & 16.660 & SerQ3 & 0.868 & 28.373 \\
\hline \multirow[t]{4}{*}{ IQ4 } & 0.716 & 8.546 & SQ6 & 0.761 & 14.973 & SerQ4 & 0.729 & 9.354 \\
\hline & & & & & & SerQ5 & 0.790 & 14.888 \\
\hline & & & & & & SerQ6 & 0.786 & 16.361 \\
\hline & & & & & & SerQ7 & 0.751 & 11.607 \\
\hline
\end{tabular}

\begin{tabular}{|c|c|c|c|c|c|c|c|c|}
\hline \multicolumn{3}{|c|}{ System use (SU) } & \multicolumn{3}{|c|}{ User satisfaction (US) } & \multicolumn{3}{|c|}{ Organizational results (OR) } \\
\hline Item & Load & $T$-statistic & Item & Load & $T$-statistic & Item & Load & $T$-statistic \\
\hline UU1 & 0.882 & 29.375 & US1 & 0.809 & 19.317 & OR1 & 0.817 & 22.968 \\
\hline UU2 & 0.877 & 33.866 & US2 & 0.906 & 51.490 & OR3 & 0.768 & 12.181 \\
\hline UU3 & 0.855 & 25.120 & US3 & 0.785 & 14.712 & OR4 & 0.835 & 26.133 \\
\hline \multirow[t]{4}{*}{ UU4 } & 0.826 & 17.087 & US4 & 0.813 & 16.879 & OR5 & 0.744 & 14.663 \\
\hline & & & & & & OR7 & 0.783 & 16.194 \\
\hline & & & & & & OR8 & 0.788 & 17.340 \\
\hline & & & & & & OR9 & 0.832 & 25.406 \\
\hline
\end{tabular}

Table 3

Reliability of the construct.

\begin{tabular}{llll}
\hline Construct & $(\alpha)$ & $(\rho \mathrm{c})$ & AVE \\
\hline Organizational results (OR) & 0.918 & 0.933 & 0.635 \\
Information quality (IQ) & 0.860 & 0.905 & 0.706 \\
System quality (SQ) & 0.764 & 0.849 & 0.585 \\
Service quality (SerQ) & 0.914 & 0.932 & 0.662 \\
User satisfaction (US) & 0.848 & 0.898 & 0.689 \\
Use-utility of the system (UU) & 0.883 & 0.919 & 0.740 \\
\hline
\end{tabular}

that the variance shared between the construct and the indicators of the same is greater than the error variance. Taking as reference the aforementioned acceptance criteria, eight indicators were eliminated (IQ5, IQ6, SQ2, SQ5, SAT5, UU5, OR6), Table 2 shows the results.

The second test consists on evaluating the reliability of the construct, which is done through two internal consistency measurements: Cronbach's Alpha $(\alpha)$ and the composite reliability coefficient $(\rho c)$, given that the interpretation of both values is similar. Therefore, the guidelines provided by Hair, Hult, Ringle, and Sarstedt (2014) are used, which suggest 0.7 as the point of reference for both Cronbach's Alpha and the composite reliability. Table 3 presents the results obtained, showing that all the constructs are reliable and, therefore, have a satisfactory internal consistency.

Another test to determine the reliability of an instrument in PLS is convergent validity, which is calculated using the Average Extracted Variance (AVE). The AVE coefficient provides the quantity of variance that a reflective construct obtains from its indicators with regard to the quantity of variance due to the measurement error. As can be observed in Table 3, the AVE coefficient for the reflective constructs is greater than 0.5 (Fornell \& Larcker, 1981). This means that more than 
Table 4

Discriminant validation matrix.

\begin{tabular}{lllllll}
\hline & OR & IQ & SQ & SerQ & US & UU \\
\hline OR & 0.797 & & & & & \\
IQ & 0.606 & 0.841 & & & & \\
SQ & 0.556 & 0.673 & 0.765 & & & \\
SerQ & 0.709 & 0.646 & 0.616 & 0.813 & & \\
US & 0.642 & 0.694 & 0.682 & 0.682 & 0.830 & \\
UU & 0.617 & 0.699 & 0.685 & 0.611 & 0.708 & 0.860 \\
\hline
\end{tabular}

Table 5

Summary of the Explained Variance $\left(R^{2}\right)$.

\begin{tabular}{ll}
\hline Construct & $R^{2}$ \\
\hline Organizational results & 0.465 \\
User satisfaction & 0.617 \\
Use-utility of the system & 0.620 \\
\hline
\end{tabular}

$50 \%$ of the variance of the construct is due to its indicators. According to these suggestions, all the AVE measurements are valid.

Finally, the discriminant validity must be evaluated, which consists on proving if the analyzed construct is significantly removed from other constructs with which it is theoretically related (Roldán, 2000). In this sense, the values of the correlation matrix between constructs were analyzed; which is comprised by the square root of the AVE coefficient and must be greater than the rest of its column (Chin, 2000; Sánchez \& Roldán, 2005). As can be observed in Table 4, all the indicators comply with the empirical criteria. Therefore, the discriminant validity of the different constructs that make up the proposed model is guaranteed.

Once it has been proven that the measurement model complies with the aforementioned criteria (the measurements of the constructs are reliable and valid), the relationship level between the constructs and the prediction capability of the endogenous variables is analyzed, evaluating the weight and magnitude of the relationships (hypothesis) between the different variables; for this, the structural model must be evaluated. This assessment entails the usage of two basic indexes: explained variance $\left(R^{2}\right)$, which indicates the predictive power of the model, and standardized path coefficients $(\beta)$, which indicate the strength of the relationships between the dependent and independent variables (Johnson, Herrmann, \& Huber, 2006).

Regarding the predictive capability of the model, the $R^{2}$ of the endogenous or dependent variables must be equal to or greater than 0.1 (Falk \& Miller, 1992), given that according to the authors, lower values provide little information. On the other hand, Chin (1998) suggests that this value must be equal to or greater than 0.19 . Parting from this last criterion, the adjusted $R^{2}$ values of the researched constructs are within desirable ranges, therefore, all the constructs hold an acceptable predictive power quality. Table 5 shows the results obtained.

Regarding the analysis of how the exogenous variables in the dependent constructs contributed to the explained variance, the values obtained in the path coefficients $(\beta)$ were used, which must have at least a value of 0.2 to be considered significant (Chin, 1998). It is worth noting that the non-parametric Bootstrap technique was utilized, with a resampling procedure with replacement, considering 133 cases with 5000 samples, as recommended for final results (Hair et al., 2014). From the aforementioned, Student's $t$ values and the significance $(p)$ were obtained. 
Table 6

Results of the structural model.

\begin{tabular}{llll}
\hline Hypothesis & Coefficient $(\beta)$ & $t$ Values & $p$ Values \\
\hline $\mathrm{H}_{1}$. Information quality $\rightarrow$ user satisfaction & $0.299^{* *}$ & 3.290 & 0.001 \\
$\mathrm{H}_{2}$. Information quality $\rightarrow$ use-utility & $0.276^{* *}$ & 2.977 & 0.003 \\
$\mathrm{H}_{3}$ System quality $\rightarrow$ user satisfaction & $0.291^{* * *}$ & 3.799 & 0.000 \\
$\mathrm{H}_{4}$ System quality $\rightarrow$ use-utility & $0.253^{* *}$ & 3.004 & 0.003 \\
$\mathrm{H}_{5}$ Service quality $\rightarrow$ user satisfaction & $0.310^{* * *}$ & 4.282 & 0.000 \\
$\mathrm{H}_{6}$. Service quality $\rightarrow$ use-utility & $0.081(\mathrm{n} . \mathrm{s})$. & 1.012 & 0.311 \\
$\mathrm{H}_{7}$. User satisfaction $\rightarrow$ organizational results & $0.411^{* * *}$ & 4.605 & 0.000 \\
$\mathrm{H}_{8}$. Perceived benefits $\rightarrow$ use-utility & $0.289^{* *}$ & 2.838 & 0.005 \\
$\mathrm{H}_{9}$ Perceived benefits $\rightarrow$ organizational results & $0.326^{* *}$ & 3.934 & 0.000 \\
\hline
\end{tabular}

$\mathrm{p}<0.05\left(^{*}\right), \mathrm{p}<0.01\left(^{* *}\right), \mathrm{p}<0.001\left(^{* * *}\right)$, n.s., not significant

Table 7

Stone-Geisser test $\left(Q^{2}\right)$.

\begin{tabular}{ll}
\hline Latent endogenous variable & $Q^{2}$ \\
\hline OR & 0.282 \\
US & 0.398 \\
UU & 0.443 \\
\hline
\end{tabular}

For a distribution of the two tailed Student's $t$ values with $n$ degrees of freedom, with $n$ being the number of samples considered in the Bootstrap technique, the values that determined the statistical significance are: $t(95 \%)=1.965^{*}, t(99 \%)=2.586^{* *}$, and $t(99.9 \%)=3.310 * * *$. As can be observed in Table 6, of the total stated hypotheses, only hypothesis H6 was not significant.

Continuing with the statistical inference, the Stone-Geisser procedure or $Q^{2}$ parameter (Cross Validated Redundancy) was used to measure the predictive capability of the model dependent constructs. This test is calculated using the blindfolding technique. The $Q^{2}$ parameter must be greater than 0 (zero) so that the construct has predictive validity (Chin, 1998), given that the values above zero show that the predictability of the model is relevant (Sellin, 1995). As can be observed in Table 7, all the $Q^{2}$ values are above zero, which supports the predictive relevance of the model in relation to the latent endogenous variables.

Lastly, the Standardized Residual of the Root Mean Square (SRMS) was calculated, this being the average difference between the predicted and observed correlations (variances and covariances) based on the residual standard deviation. Therefore, it can be considered a goodness of fit measurement (model) for PLS-SEM (Henseler et al., 2014). Given that the SRMS is an absolute measurement, a value of zero indicates a perfect fit, but values below 0.08 are generally considered a good fit (Hu \& Bentler, 1999). In this sense, the SRMS value obtained from the model of this investigation is of 0.062 , which indicates an adequate level of adjustment.

After carrying out the inferential statistical analysis, it was observed that eight of the nine hypotheses were accepted with an explained variance of $46.5 \%$, which corroborates the predictive level of the model; Fig. 2 shows the results obtained in a graph. 


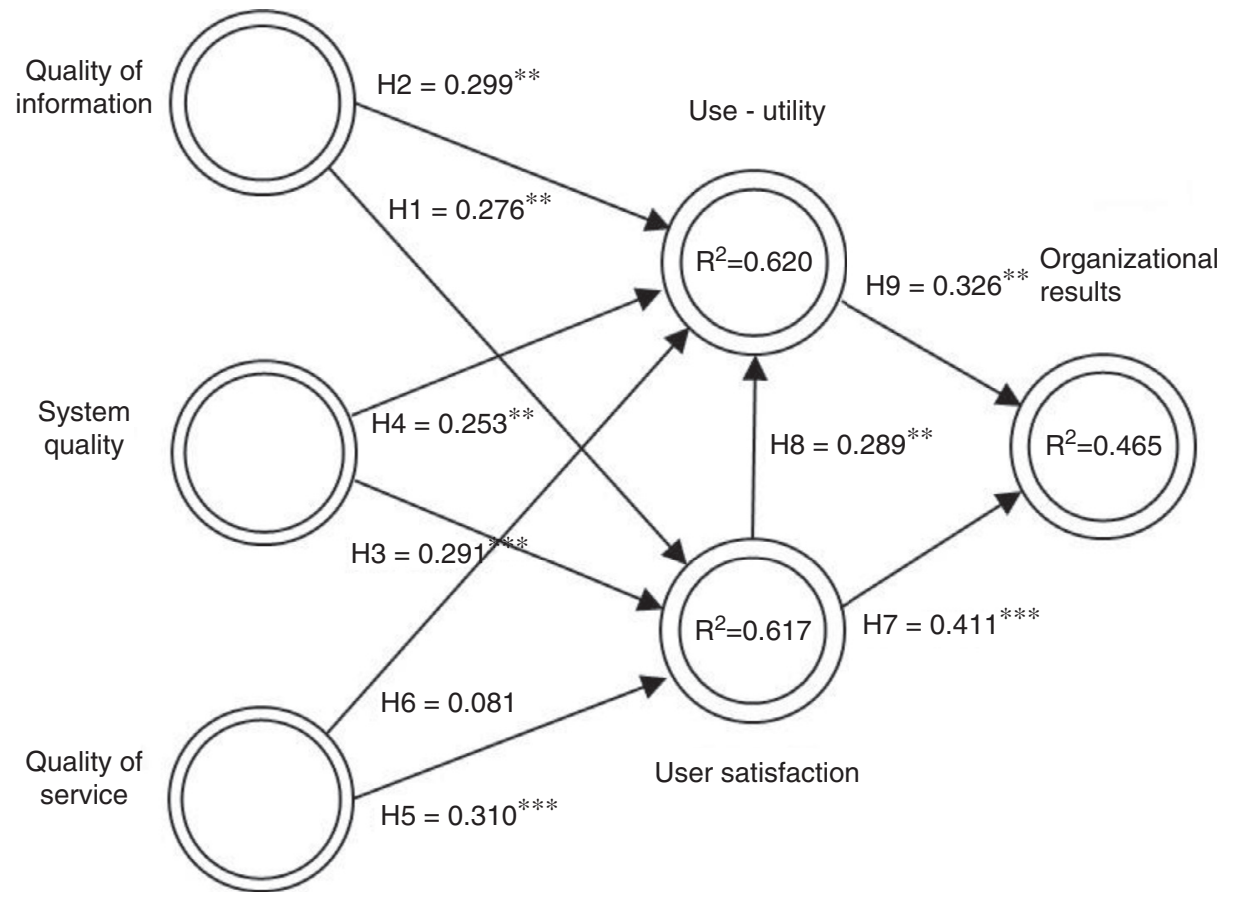

Fig. 2. Research model assessed.

\section{Hypothesis contrast}

The results show that the quality of the information has positive and statistically significant values for the User Satisfaction and Use-Utility variables $\left(\mathrm{H}_{1}=0.299\right.$ and $\left.\mathrm{H}_{2}=0.276\right)$. Therefore, they are accepted and consequently this suggests that the SMEs with Information Systems that provide timely, up to date, useful, relevant, and exact information with a good level of detail and easy to interpret, obtain a better user performance. That is, it is considered that the use of quality data is a secure source for user satisfaction in terms of having information in accordance with their needs, and allows them to make better and faster decisions. These results are similar to those obtained by Floropoulos, Spathis, Halvatzis, and Tsipouridou (2010), Nunes (2012) and Solano et al. (2014), and partially analogous to those obtained by Roldán and Leal (2003), Calderón and Rodríguez (2010) and Pérez (2010), due to these find significant relation only with regard to user satisfaction.

Regarding system quality (hypotheses $\mathrm{H}_{3}$ and $\mathrm{H}_{4}$ ), positive and significant coefficients can be observed with the user satisfaction and use-utility constructs $\left(\mathrm{H}_{3}=0.291, \mathrm{H}_{4}=0.253\right)$. Therefore, the hypotheses are accepted, derived from the users perceiving that the Information System is easy to use, user-friendly, does not fail, is quick and compatible with other systems utilized in the institution, which allows them to reduce costs, understand the needs of the clients, have a better selection of suppliers, and improve the internal efficiency, among others. The results obtained are similar to those found by Pérez (2010), Nunes (2012), Tona et al. (2012) and Wang (2008), in the sense that in all of them a strong relationship is detected between the construct and its latent variables. 
Regarding the quality of the IT services in relation to the use-utility of the system, hypothesis $\mathrm{H}_{5}$ does not have statistical support, therefore, it is not accepted. In the analyzed SMEs, this relation is found due to either outsourcing of the service or the lack of training in the manner of providing the service. On the other hand, regarding user satisfaction, the results show a positive and statistically significant value $\left(\mathrm{H}_{5} \beta=0.310 ; p>0.001\right)$. These results are partially similar to those obtained by Wang (2008), Pérez (2010) and Nunes (2012), since the authors find that it significantly influences its latent variables. However, in this investigation it is only reflected in user satisfaction. Even then, the study provides empirical support to the construct in question by determining that it does influence the perception of success of an information system.

As for user satisfaction, it is worth emphasizing that hypothesis $\mathrm{H}_{8}(\beta=0.289 ; p>0.001)$ was accepted, which demonstrates that this construct exercises significant influence on the use-utility of the system, meaning the users feel satisfied with the qualities of the system and, therefore, are motivated to use it. The results are in line with those of McGill and Hobbs (2003) and Kettinger, Park, and Smith (2009).

Finally, the use-utility and user satisfaction hypotheses were accepted, given that they showed positive and statistically significant coefficients with the organizational results $\left(\mathrm{H}_{9}=0.326\right.$, $\mathrm{H}_{7}=0.411$ ), which demonstrates that these variables have a significant effect on the organizational impact. The aforementioned is relevant for the success of an IS, given that it indicates that the respondents perceive increases in the productivity, internal efficiency, or a decrease in the operational costs, meaning they distinguish the IS as a means of improving business performance, being consistent with what was reported by Gable, Sedera, and Chan (2003), DeLone and McLean (2003), Medina (2005), Abrego, Sánchez, and Medina (2014), and Solano et al. (2014). Finally, it is perceived that user satisfaction contributes the most with a $\beta$ of 4.11 . This could suggest that the SMEs that are concerned with providing their system users with quality characteristics will have as a result a greater individual performance (user satisfaction, use-utility of the system), which will lead to an improvement of the organizational results.

\section{Conclusions, administrative implications, and limitations}

In this document, aspects relevant to the success of the IS and their impact in the management of companies were investigated, in accordance with the research trends in the IS area (Petter et al., 2008, 2013) and based on the model proposed by DeLone and McLean (2003). This was done with the purpose of having other perspectives regarding their impacts outside of developed countries and thus to contribute to the development of studies on the impact of IS on Mexican SMEs, all the while considering that the studied economic units contribute in a relevant manner to the development of the research environment.

Several conclusions are obtained based on the findings. First, the results of the empirical analysis indicate that information quality is the most important precedent for user satisfaction and for the utility of the IS, given that the users consider the availability and accuracy of the information to be a key element for the successful implementation of a system, followed by the quality of the system, and the service. Nevertheless, by considering the three elements of quality (information, system and service) as a whole, the influence of said elements on satisfaction and utility of the users can be considered from substantial to moderate, which allows inferring that more support on behalf of the organizational direction for the dimensions of quality of the IS could contribute to a better individual performance (use-utility, user satisfaction).

This generates implications for the system designers, who have to address the needs of the end users and make full use of the completeness, security, availability, speed, and accuracy of the 
information to increase user satisfaction, but specially to improve the intention of use-utility of the system.

Similarly, we conclude that the users that achieved greater satisfaction are motivated toward a greater use of the IS, where a greater satisfaction and use lead to better results at the organizational level. This could support companies in their decisions to invest in technology, given that it would allow to increase the quality of services, contributing to the organizational performance. In other words, the organizations with greater technological infrastructure, development methodologies, and competence of their programmers, improve the results of the quality of the system, contributing to the individual and organizational development of the company (Solano et al., 2014). Thirdly, the proposed model and its elements demonstrated that they can be used as a beneficial tool by the organizations to assess the implementation of the IS, given that the results implied an adequate predictive power for the utilized variables. Thus, highlighting the importance that the organizations must place in the assessment of the IS in order to guarantee a true internal benefit.

The results obtained could be useful for the administrators and IT managers in terms of structuring of policies, allowing them a better integration of these types of technologies with regard to the business strategies, all to allocate the scarce resources more efficiently. Likewise, they can be of use in higher level educational institutions, given that the results could be used as a base to design and update study programs, as well as to promote further investigations that contribute to strengthening the literature regarding the success of the IS in the organizations, derived from the limitations found to determine it at an organizational level. Finally, this work contributes to the literature on the measurement of the success of the IS in the context of a country with an emerging economy, and in particular in allowing to fully identify the measurement of its effectiveness and incidence in the performance variables.

On the other hand, this investigation has its limitations. First, the validity of a model cannot be truly established based on a single study, given that the data represent a moment in time. Secondly, the study was performed in a determined geographical context (state of Tamaulipas, Mexico). Therefore, care should be taken when generalizing the results, and the criticisms to the cause-effect relations between the constructs in the model should be done with caution.

Therefore, we invite researches and practitioners to make future works that take into consideration a more diversified universe of companies, as well as to contemplate other geographical regions different from the one studied in this work. Furthermore, future studies should consider investigating the causes of success of the IS or, where applicable, how they influence on the perception of the same, given that currently there are gaps in the knowledge of these factors.

\section{Acknowledgements}

Our most sincere appreciation for the logistical and financial support to the investigation goes to PIFI P/PROSOCIE-2014-28MSU0010B-15 and Fondos UAT.

\section{References}

Abrego, D., Sánchez, Y., \& Medina, J. (2014). Evaluación de la calidad de los sistemas de información en los resultados y capacidades organizacionales de empresas del noreste de México. In XIX Congreso Internacional de Investigación en Contaduría, Administración e Informática

Andreu, R., Ricart, J., \& Valor, J. (1996). Estrategia y sistemas de información (2a ed.). Madrid: Mc Graw-Hill.

Bakos, Y., \& Treacy, M. (1986). Information technology and corporate strategy: A research perspective. MIS Quarterly, 10, 107-119. http://dx.doi.org/10.2307/249029 
Ballantine, J., Bonner, M., Levy, M., Martin, A., Munro, I., \& Powell, P. (1996). The 3-D model of information systems success: The search for the dependent variable continues. Information Resources Management Journal, 9(4), 5-14. http://dx.doi.org/10.4018/irmj.1996100101

Ballou, P., \& Tayi, K. (1999). Enhancing data quality in data warehouse environments. Communications of the ACM, 42(1), 73-78. http://dx.doi.org/10.1145/291469.291471

Baroudi, J., Olson, M., \& Ives, B. (1986). An empirical study of the impact of user involvement on system usage and information satisfaction. Communications of the ACM, 29(3), 232-238. http://dx.doi.org/10.1145/5666.5669

Bharati, P., \& Berg, D. (2005). Service quality from the other side: Information systems management at Duquesne light. International Journal of Information Management, 25, 367-380. http://dx.doi.org/10.1016/j.ijinfomgt.2005.04. 008

Bharati, P., \& Chaudhury, A. (2006). Product customization on the web: An empirical study of factors impacting choice board user satisfaction. In Management Science and Information Systems Faculty Publication Series. Paper 14. Available in: http://scholarworks.umb.edu/msis faculty pubs/14 Accessed 15.08.14

Bokhari, R. (2005). The relationship between system usage and user satisfaction: A meta-analysis. The Journal of Enterprise Information Management, 18, 211-234. http://dx.doi.org/10.1108/17410390510579927

Bradley, R., Pridmore, J., \& Byrd, T. (2006). Information systems success in the context of different corporate cultural types: An empirical investigation. Journal of Management Information Systems, 23, $267-294$. http://dx.doi.org/10.2753/MIS0742-12222302011

Caldeira, M., \& Ward, J. (2002). Understanding the successful adoption and use of IS/IT in SMEs: An explanation from Portuguese manufacturing industries. Information Systems Journal, 12(2), 121-152. http://dx.doi.org/10. 1046/j.1365-2575.2002.00119.x

Calderón, J., \& Rodríguez, C. (2010). Efecto de las estrategias competitivas y los recursos y capacidades orientados al mercado sobre el crecimiento de las organizaciones. Contaduría y Administración, 57(1), 79-102.

Carmines, G., \& Zeller, R. (1979). Reliability and validity assessment. In Sage university paper series on quantitative applications in the social sciences. Beverly Hills: Sage., series nos. 07-017.

Carr, C. (2002). A psychometric evaluation of the expectations, perceptions, and difference-scores generated by the IS-adapted SERVQUAL instrument. Decision Sciences, 33, 281-296. http://dx.doi.org/10.1111/j. 1540-5915.2002.tb01645.x

Casaló, L., Flavián, C., \& Guinalíu, M. (2011). Redes sociales virtuales desarrolladas por organizaciones empresariales: Antecedentes de la intención de participación del consumidor. Cuadernos de Economía y Dirección de la Empresa, 15, 42-51. http://dx.doi.org/10.1016/j.cede.2011.06.003

Chen, L., Soliman, K., Mao, E., \& Frolick, M. (2000). Measuring user satisfaction with data warehosues: An exploratory study. Information and Management, 37(3), 103-110. http://dx.doi.org/10.1016/S0378-7206(99)00042-7

Chin, W. (1998). Issues and opinion on structural equation modeling. MIS Quarterly, 22(1), 7-17.

Chin, W. (2000). Partial Least Square for researchers: An overview and presentation of recent advances using the PLS approach.. Available in: http://disc-nt.cba.uh.edu/chin/icis2000plstalk.pdf Accessed 22.07.14

Choe, J. (1996). The relationships among performance of accounting information systems, influence factors, and evolution level of information systems. Journal of Management Information Systems, 12(4), 215-239. http://dx.doi. org/10.1080/07421222.1996.11518107

Croteau, A., \& Bergeron, F. (2001). An information technology trilogy: Business strategy, technological deployment and organizational performance. Journal of Strategic Information Systems, 10(2), 77-99. http://dx.doi.org/10. 1016/S0963-8687(01)00044-0

Davis, G., \& Olson, M. (1985). Management information systems: Conceptual foundations, structure, and development. New York: McGraw-Hill.

DeLone, W., \& McLean, E. (1992). Information systems success: The quest for the dependent variable. Information Systems Research, 3(1), 61-95. http://dx.doi.org/10.1287/isre.3.1.60

DeLone, W., \& McLean, E. (2003). The DeLone and McLean model of information systems success: A ten-year update. Journal of Management Information Systems, 14(9), 9-30.

Derksen, B., \& Luftman, J. (2013). Management and technology trends for IT executives. Compact International Magazine, 6-15. Available in: http://www.jstor.org/stable/40398184 Accessed 17.04.14

Díaz, M., \& Sligo, J. (1997). How software process improvement helped Motorola. IEEE Software, 14(5), 75-81. http://dx.doi.org/10.1109/52.605934

Falk, R., \& Miller, N. (1992). A primer for soft modeling. Akron: The University of Akron Press.

Ferreira, R., \& Cherobim, A. (2012). Impacts of investments in it on the organizational performance of baking companies of minas Gerais state: A multicase study. Revista de Administracão e Contabilidade da Unisinos, 9(2), $147-161$. http://dx.doi.org/10.4013/base.2012.92.04 
Fitzgerald, G., \& Russo, N. (2005). The turnaround of the London ambulance service computer-aided dispatch system (LAS-CAD). European Journal of Information Systems, 14(3), 244-257. http://dx.doi.org/10. 1057/palgrave.ejis.3000541

Floropoulos, J., Spathis, C., Halvatzis, D., \& Tsipouridou, M. (2010). Measuring the success of the Greek taxation information system. International Journal of Information Management, 30, 47-56. http://dx.doi.org/ 10.1016/j.ijinfomgt.2009.03.013

Fornell, C., \& Larcker, D. (1981). Evaluating structural equation models with unobservable variables and measurement error. Journal of Marketing Research, 18, 39-50. http://dx.doi.org/10.2307/3151312

Gable, G., Sedera, D., \& Chan, T. (2003). Enterprise systems success: A measurement model. In S. T. March, A. Massey, \& J. I. DeGross (Eds.), Twenty-fourth international conference on information systems (pp. 576-591). Seattle, USA: Association for Information Systems.

Gable, G., Sedera, D., \& Chan, T. (2008). Re-conceptualizing information system success: The IS-impact measurement model. Journal of the Association for Information Systems, 9(7), 377-408.

Gómez, A., \& Suárez, R. (2012). Sistemas de información herramientas prácticas para la gestión empresarial (4a ed.). Madrid, Spain: Alfaomega.

Gonzáles, R. (2012). Impacto de la Data Warehouse e Inteligencia de Negocios en el Desempeño de las Empresas: Investigación Empírica en Perú, Como País en Vías de Desarrollo. Barcelona: Universitat Ramon Llull. ESAN Política de Empresa, Dirección Recursos Humanos y Sistemas de Información. Tesis inédita.

Gorla, N., Somers, T., \& Wong, B. (2010). Organizational impact of system quality, information quality, and service quality. Journal of Strategic Information Systems, 19, 207-228. http://dx.doi.org/10.1016/j.jsis.2010.05.001

Haag, S., \& Cummings, M. (2013). Management information systems for the information age (9th ed.). USA: McGrawHill Education.

Haberkamp, A., Maçada, A., Raimundini, S., \& Bianchi, M. (2010). Impacto dos investimentos em tecnologia da informacãonas variáveis estratégicas das empresas prestadoras de servicos contábeis. Revista de Administracão $e$ Contabilidadeda Unisinos, 7(2), 149-161. http://dx.doi.org/10.4013/base.2010.72.06

Hair, J., Hult, G., Ringle, C., \& Sarstedt, M. (2014). A primer on partial least squares structural equation modeling (PLS-SEM). Thousand Oaks: Sage.

Halawi, L., McCarthy, R., \& Aronson, J. (2007). An empirical investigation of knowledge management systems success. Journal of Computer Information Systems, 48(2), 121-135.

Henseler, J., Dijkstra, T., Sarstedt, M., Ringle, C., Diamantopoulos, A., Straub, D., et al. (2014). Common beliefs and reality about partial least squares: Comments on Rönkkö \& Evermann (2013). Organizational Research Methods, 17(2), 182-209. http://dx.doi.org/10.1177/1094428114526928

Heo, J., \& Han, I. (2003). Performance measure of information systems (IS) in evolving computing environments: An empirical investigation. Information \& Management, 40(4), 243-256. http://dx.doi.org/10. 1016/S0378-7206(02)00007-1

Hu, L., \& Bentler, P. (1999). Cutoff criteria for fit indexes in covariance structure analysis: Conventional criteria versus new alternatives. Structural Equation Modeling, 6, 1-55. http://dx.doi.org/10.1080/10705519909540118

Hwang, M., Windsor, J., \& Pryor, A. (2000). Building a knowledge base for MIS research: A meta-analysis of a systems success model. Information Resources Management Journal, 13(2), 26-32. http://dx.doi.org/10.4018/irmj. 2000040103

Igbaria, M., \& Tan, M. (1997). The consequences of information technology acceptance on subsequent individual performance. Information \& Management, 32(3), 113-121. http://dx.doi.org/10.1016/S0378-7206(97)00006-2

Johnson, M., Herrmann, A., \& Huber, F. (2006). The evolution of loyalty intentions. Journal of Marketing, 70(2), $122-132$. http://dx.doi.org/10.1509/jmkg.70.2.122

Kettinger, J., \& Lee, C. (1994). Perceived service quality and user satisfaction with information services function. Decision Sciences, 25(5), 737-766. http://dx.doi.org/10.1111/j.1540-5915.1994.tb00829.x

Kettinger, W., Park, S. H., \& Smith, J. (2009). Understanding the consequences of information systems service quality on IS service reuse. Information \& Management, 46, 335-341. http://dx.doi.org/10.1016/j.im.2009.03.004

Kim, M., Moon, Y., \& Kim, W. (2012). How user-created-content (UCC) service quality influences user satisfaction and behaviour. Canadian Journal of Administrative Sciences, 29, 255-267. http://dx.doi.org/10.1002/cjas.1218

Law, C., \& Ngai, E. (2007). ERP systems adoption: An exploratory study of the organizational factors and impacts of ERP success. Information \& Management, 44(4), 418-432. http://dx.doi.org/10.1016/j.im.2007.03.004

Lee, R. (2012). Does the success of information systems really matters to firm performance? iBusiness, 4, 98-107. http://dx.doi.org/10.4236/ib.2012.42012

Livari, J. (2005). An empirical test of the DeLone-McLean model of information system success. The DATA BASE for Advances in Information Systems, 36(2), 8-27. http://dx.doi.org/10.1145/1066149.1066152 
Lunardi, G., Dolci, P., \& Maçada, A. (2010). Adocão de tecnologia de informacão e seu impacto no desempenho organizacional: Um estudo realizado com. Revista de Administracão — RAUSP, 45(1), 5-17. http://dx.doi.org/10.1590/S0080-21072010000100001

Mahmood, M., \& Soon, S. (1991). A comprehensive model for measuring the potential impact of information technology on organizational strategic variables. Decision Sciences, 22, 869-897. http://dx.doi.org/10.1111/j. 1540-5915.1991.tb00368.x

McGill, T., \& Hobbs, V. (2003). User-developed applications and information systems success: A test of DeLoneand McLean's model. Information Resources Management Journal, 16(1), 24-45. http://dx.doi. org/10.4018/irmj.2003010103

McGill, T., Hobbs, V., \& Klobas, J. (2000). Testing the DeLone and McLean Model of IS success in the user developed application domain. In 11th Australasian Conference on Information Systems.

Medina, J. (2005). Evaluación del impacto de los sistemas de información en el desempeño individual del usuario: Aplicación en instituciones universitarias. Universidad Politécnica de Madrid. Tesis inédita.

Medina, J., \& Chaparro, J. (2007). The impact of the human element in the information system quality for decision making and user satisfaction. Journal of Computer Information Systems, 48(2), 44-52.

Medina, J., Lavín, J., \& Pedraza, N. (2011). Seguridad en la administración y calidad de los datos de un sistema de información contable en el desempeño organizacional. Contaduría y Administración, 57(4), 11-34.

Nelson, R., Todd, P., \& Wixom, B. (2005). Antecedents of information and system quality: An empirical examination within the context of data warehousing. Journal of Management Information Systems, 21, 199-235.

Nunes, G. (2012). Estudio de satisfacción del usuario de sistemas de información en hospitales universitarios del nordeste(Brasil). España: DEHESA, Universidad de Extremadura. Tesis inédita.

Pérez, B. (2010). Validity of DeLone and McLean's model of information systems success at the web site level of analysis. EUA: Louisiana State University. Tesis inédita.

Pérez, J., \& Machado, A. (2015). Relationship between management information systems and corporate performances. Revista de Contabilidad - Spanish Accounting Review, 18(1), 32-43. http://dx.doi.org/10.1016/j.rcsar.2014.02.001

Pesado, P., Bertone, R., Esponda, S., Pasini, A., Boracchia, M., Martorelli, S., et al. (2013). Mejora de procesos en eldesarrollo de sistemas de software y en procesos de gestión. Experiencias en PyMEs. In XV Workshop de Investigadores en Ciencias de la Computación (pp. 581-585).

Petter, S., DeLone, W., \& McLean, E. (2008). Measuring information systems success: Models, dimensions, measures, and interrelationships. European Journal of Information Systems, 17, 236-263. http://dx.doi.org/10.1057/ejis.2008.15

Petter, S., DeLone, W., \& McLean, E. (2013). Information systems success: The quest for the independent variables. Journal of Management Information Systems, 29(4), 7-62. http://dx.doi.org/10.2753/MIS0742-1222290401

Pitt, L., Watson, R., \& Kavan, C. (1995). Service quality: A measure of information systems effectiveness. MIS Quarterly, 19(2), 173-192. http://dx.doi.org/10.2307/249687

Qutaishat, F., Khattab, S., Zaid, M., \& Al-Manasra, E. (2012). The effect of ERP successful implementation on employee's productivity, service quality and innovation: An empirical study in telecommunication sector in Jordan. International Journal of Business and Management, 7(19), 45-54. http://dx.doi.org/10.5539/ijbm.v7n19p45

Rai, A., Lang, S., \& Walker, R. (2002). Assessing the validity of IS success models: An empirical test and theoretical analysis. Information Systems Research, 13(1), 50-69. http://dx.doi.org/10.1287/isre.13.1.50.96

Rai, A., Patnayakuni, R., \& Seth, N. (2006). Firm performance impacts of digitally enabled supply chain integration capabilities. MIS Quarterly, 30(2), 225-246.

Ravichandran, T., \& Lertwongsatien, C. (2005). Effect of information systems resources and capabilities on firm performance: A resource based perspective. Journal of Management Information Systems, 21, 237-276.

Ringle, C., Wende, S., \& Becker, J. (2014). Smartpls 3. Hamburg: SmartPLS. Available in: http://www.smartpls.com Accessed 22.10.14

Roldán, J. (2000). Sistemas de información ejecutivos EIS. Génesis, implantación y repercusiones organizativas. Universidad de Sevilla. Tesis doctoral inédita.

Roldán, J., \& Leal, A. (2003). A validation test of an adaptation of the DeLone and McLean's model in the Spanish EIS field. In J. Cano (Ed.), Critical reflections on information systems: A systemic approach (pp. 66-84). Hershey, PA: Idea Group Publishing.

Sabherwal, R., Jeyaraj, A., \& Chowa, C. (2006). Information system success: Individual and organizational determinants. Management Science, 52(12), 1849-1864. http://dx.doi.org/10.1287/mnsc.1060.0583

Sánchez, M., \& Roldán, J. (2005). Web acceptance and usage model. A comparison between goal-directed and experientialweb users. Internet Research, 15(1), 21-48. http://dx.doi.org/10.1108/10662240510577059

Seddon, P. (1997). A respecification and extension of the DeLone and McLean model of IS success. Information System Research, 8(3), 240-253. http://dx.doi.org/10.1287/isre.8.3.240 
Seddon, P., \& Kiew, M. (1994). A partial test and development of the DeLone and McLean model of IS success. Proceedings of the International Conference on Information Systems, 99-110.

Sedera, D., \& Gable, G. (2004). A factor and structural equation analysis of the enterprise systems success measurement model. In Twenty-Fifth International Conferences on Information Systems. Available in: http://citeseerx.ist.psu.edu/viewdoc/download?doi=10.1.1.86.1714\&rep=rep1\&type=pdf Accessed 05.06.14

Sellin, N. (1995). Partial least square modeling in research on educational achievement. In H. Wilifred Bos, Rainer, \& yLehmann (Eds.), Reflections on educational achievement (pp. 256-267). New York, USA: Waxmann Munster.

Sethi, V., \& King, W. (1994). Development of measures to assess the extent to which an information technology application provides competitive advantage. Management Science, 40, 1601-1627. http://dx.doi.org/10.1287/mnsc.40.12.1601

Shin, B. (2003). An exploratory investigation of system success factors in data warehousing. Journal of the Association of Information Systems, 4, 141-168.

Solano, O., García, D., \& Bernal, J. (2014). Influence of the implementation of information systems on performance in small and mid-sized enterprises: An empirical study in Colombia. Cuadernos de Administración, 30(52), 31-43.

Straub, D. (1989). Validating instruments in MIS research. MIS Quarterly, 13, 147-190. http://dx.doi.org/10.2307/248922

Tallon, P., Kraemer, L., \& Gurbaxani, V. (2000). Executives' perceptions of the business value of information technology: A process-oriented approach. Journal of Management Information Systems, 16, 145-173. http://dx.doi.org/10.1080/07421222.2000.11518269

Taylor, S., \& Todd, P. (1995). Understanding information technology usage: A test of competing models. Information Systems Research, 6(2), 144-176. http://dx.doi.org/10.1287/isre.6.2.144

Tona, O., Carlsson, S., \& Eom, S. (2012). An empirical test of DeLone and McLean's information system success model in a public organization. AMCIS 2012 Proceedings,. Paper 10. Available in: http://aisel.aisnet.org/ amcis2012/proceedings/StrategicUseIT/10 Accessed 10.11.14

Torkzadeh, G., \& Dwyer, D. (1994). A path analytic study of determinants of information system usage. Omega, 22(4), 339-348. http://dx.doi.org/10.1016/0305-0483(94)90060-4

Turban, E., Volonino, L., \& Wood, R. (2013). Information technology for management: Advancing sustainable, profitable business growth (9th ed.). USA: John Wiley \& Sons.

Urbach, N., Smolnik, S., \& Riempp, G. (2009). The state of research on information systems success. Business \& Information Systems Engineering, 1(4), 315-325. http://dx.doi.org/10.1007/s12599-009-0059-y

Vázquez, S. (2015). Medición de la Calidad del Servicio para Agentes de Suscripción en Revistas Digitales a través del Modelo Servqual. GECONTEC Revista Internacional de Gestión del Conocimiento y la Tecnología, 3(1), 53-68.

Wang, Y. (2008). Assessing e-commerce systems success: A respecification and validation of the DeLone and McLeanmodel of IS success. Information Systems Journal, 18, 529-557. http://dx.doi.org/10.1111/j.1365-2575.2007.00268.x

Wixom, B., \& Todd, P. (2005). A theoretical integration of user satisfaction and technology acceptance. Information Systems Research, 16(1), 85-102. http://dx.doi.org/10.1287/isre.1050.0042

Wixom, B., \& Watson, H. (2001). An empirical investigation of the factors affecting data warehousing success. MIS Quarterly, 25(1), 17-41. http://dx.doi.org/10.2307/3250957

Wu, J., \& Wang, Y. (2006). Measuring KMS success: A respecification of the DeLone and McLean's model. Information and Management, 43, 728-739. http://dx.doi.org/10.1016/j.im.2006.05.002

Ynzunza, C., \& Izar, J. (2011). Efecto de las estrategias competitivas y los recursos y capacidades orientados al mercado sobre el crecimiento de las organizaciones. Contaduría y Administración, 58(1), 169-197. http://dx.doi.org/10.1016/S0186-1042(13)71202-6 